\title{
RARE AND UNIQUE NAMES OF "NON-INDO-EUROPEAN" TYPE AND THE CASE OF DALLÁN FORGAILL
}

\author{
NINA ZHIVLOVA
}

\section{Introduction}

The study of Old Irish onomastics began in the $19^{\text {th }}$ century with John O'Donovan - as did many other lines of research in medieval Irish culture and language (O'Donovan 1862: 51-9). The $20^{\text {th }}$ century Irish scholars M. A. O'Brien and B. Ó Cuív were major contributors to the subject (CGH; O'Brien 1973; Ó Cuív 1980-81, 1986).

Two-part compound names connected with notions of war, fame and power and with animals like the wolf and horse were popular among speakers of many Indo-European language branches (Indian, Iranian, Greek, Germanic, Slavic and Celtic). This "Indo-European" type of composita, probably inherited from Proto-Indo-European language (and culture) was studied in detail by Uhlich (1993).

At the same time there is another Old Irish name-type consisting of a noun + adjective or a noun + noun in genitive case, for example, Mac Menman 'son of thought'. This name-type was described by M.A. O'Brien and other scholars as "Non-Indo-European" (O'Brien 1973), hereafter "Non-IE". I accept this conventional term, without necessarily implying, however, that I agree that this name-type was inherited from a "Non-Indo-European" substrate.

Study of this name-type is long overdue. To date there have only been a few studies dedicated to certain name-types and to particular first and second elements in the names of "Non-IE" type (e.g. Dobbs 1947, O'Brien 1956, Clancy 2004, and Doherty 2006). At present, I am working on a comprehensive study of such names, which would include a study of their temporal and spatial distribution, a study of the semantics of the second elements and the factors which could have influenced the choice of a certain second element.

As the first element of a "Non-IE" name the following most often appear: Cenn 'head', Cú 'dog', Donn 'dark', Dub 'black', Fer 'man, husband', Macc 'son, boy', Máel 'shaven (?), tonsured (?), bald (?)', Mess(en) 'fosterling', Nia 'hero / nephew'. Female names could take as a first element Der 'daughter' (O'Brien 1956), Bé 'woman', but "male" Dub (e.g. Dub Coblaigh) and Máel (e.g. Máel Muire) can be also used. Later (in the Middle Irish period after 900) a new type appears, with Gilla 'servant, gillie' as the first element. Cé(i)le 'client, friend, retainer' was current as a first element of 
personal names in the $8^{\text {th }}-9^{\text {th }}$ centuries and was used (as far I am aware) only by clerics.

At the same time there are other, rarer types (like one beginning with Cáech 'one-eyed') and some unique names which are constructed according to the "Non-IE" model; thus, their first element can be a unique example of a type. Those names are sometimes not recognized for what they are, and described as "nicknames". The aim of this study is to show that they are not accidental word-play but a part of general Old Irish pattern of name-giving.

\section{Some rare and unique "Non-IE" name types}

\subsection{Becc 'small' and bécc (?)}

There is a number of names which can be regarded as "Non-IE" and include becc as the first element. However, Becc 'small' is used as a personal name (hereafter PN) by itself. In fact two distinct PNs are attested - a masculine $o$ stem adjective Becc (genitive Bicc) 'small' and a feminine $a$-stem noun (?) Bécc (genitive Béicce). ${ }^{1}$ Without a genitive it is sometimes hard to distinguish becc and bécc. The etymology of Bécc is unknown (Thurneysen 1946: 183, CGH: 517). ${ }^{2}$

The most famous is a king or prince of Ulaid, Becc Bairche (d. 718); ${ }^{3}$ the first element here is bécc as evidenced by $m$. Béicce Bairche (CGH). Becc Baile, son of Eochu (d. 744) was probably also a layman.

The first element bécc / becc was, as it seems, often used in the names of clerics. Saint Becc Bile m. Síláin (CGSH 304) was one of four brothers (the other three are Cuan, Colman and Connadil). The name of bishop Becc Fhola (d. 694, AU) is probably derived from fuil 'blood'. This name is homonymous with the name of the mysterious lady Becfhola from Tochmarc Becfhola (Bhreathnach, 1984). The woman's name is usually explained as based on folud 'wealth, obligations, essence' and meaning something like 'one who is of little value' (Bhreathnach, 1984: 87; Findon, 2013: 62). It can be tentatively suggested that this is actually a "folk" etymology and that fola in both names is a genitive of fuil 'blood', which is consistent with the "Non-IE" names' building pattern.

Another bishop, known from the genealogies, is Bec[c] Fine (CGHS 704.147). The name of an abbot of Clonard Becc Laitne (d. 763, AU), could be a clerical nickname / second name based on Laiten 'Latin', but we do not have any direct evidence for that in this case (as well as in other cases, see below).

It may be suggested that the names including Old Irish becc 'small' were given (in boyhood?) to clerics, signifying modesty and humiliation, appropriate for a cleric. However, with the exception of Becc Laitne, the

\footnotetext{
${ }^{1}$ This is one of the most common Old Irish PNs (O’Brien 1973: 232).

${ }^{2}$ Cf. béiccid 'roars, bellows'.

${ }^{3}$ All dates are given as in Charles-Edwards 2006.
} 
second elements do not contain anything especially clerical about them and it must be kept in mind that the first element is often not becc but the enigmatic bécc. The name Bécc Tethba (CGH $144 \mathrm{~d}$ 6) may be a nickname denoting this person's place of origin (Bécc of Tethba, and not, for example, Bécc of Mide), but it also could be a PN including a notable geographical / topographical feature, as, for example, Becc Bile (bile '(sacred) tree') (Ó Cuív 1980-1: 10).

\subsection{Cáech 'one-eyed, purblind'}

Cáech 'one-eyed' may also serve as a first element in a "non-IE" name. This rare first element was accepted as such by B. Ó Cuív in his study of geographic elements in Irish personal names (Ó Cuív 1980-1).

Two personal names of this kind occur in CGH: Cáech Maige (CGH LL 324 c 46) and Cáech Thuile (CGH 160 b 45). The list of names of tribes adds further examples: Cáech Luinge (Meic Cáechluingi of Uí Fidgente: from long 'ship'; CGH 152 a 27) and Cáech Tangéni (Uí Chaechtangéni; probably from tangnae 'treachery, deceit': CGH 120 ac 32). Uí Caích Crónchae are probably of the same type (CGH 125 a 5). The only such name which is mentioned in the annals is probably Cáech Scuile, scribe of Doire Calgaigh (d. 724, AU), although this PN ('the one-eyed one of a school') could indeed be a nickname.

\subsection{Doél 'chafer'}

We can also (very tentatively) suggest that the word doél 'chafer' was used as a first element in the names of "Non-IE" types (perhaps, as a synonym of $d u b$ 'black'). Doél appears as a first element in the following names of IE type: Doélgal (like Fergal, Bodbgal from - gal 'heat, rage'); Doélgus (like Fergus, Óengus from -gus 'power') (Uhlich 1993: 115); Doilgen (cf. Fingen, Aithgen from -gen 'infant, human being'). In Old and Middle Irish doél could be a term of approval and even of praise. ${ }^{4}$

In the name of a personage in the Ulster cycle of tales, Dubtach Doél Ulad, the last two words were understood as a nickname ('the chafer of the Ulaid'). Another name including doél is Doél Dermait 'Doél the Forgotten One', mentioned in the Old Irish tale Fled Bricrenn ocus Loinges nac nDuíl Dermait (Hollo 2005: 78-9).

However, there is some evidence that Doél could be perceived as the first element of a "Non-IE" PN. Tromdámh Guaire contains a fanciful list of poets from different places (including a Welshman and an Anglo-Saxon). The names are obviously invented for the sake of humour but for most part they follow real models of Old Irish PN-formation: for example, Máel Gedic ('máel of the gosling') son of Fir Goboc ('man of a little beak'). The ollam of Leinster is named Dáel Duiled, the 'chafer of creations' (Joynt 1931: 7).

\footnotetext{
${ }^{4}$ Cf. húasal dóel diasnéti 'noble and indescribable beetle' of Colum Cille: DIL, s.v. doél.
} 


\subsection{Túaim 'mound' (?)}

A unique case, to my knowledge, is the name of Túaim Snáma, son of Fland, king of Osraige (d. 770). Túaim is explained in DIL as 'bend, arch; mound; boss of shield'; snám is 'swimming'. This name ('the mound of swimming') looks like a toponym, but it is attested as a PN both in the annals and genealogies (CGH 129 b 44). I do not know of any other example of the use of túaim as the first element of a PN.

\section{Dall 'blind' and the case of Dallán Forgaill}

\subsection{Dallán Forgaill and his poem}

Dallán Forgaill, the $6^{\text {th }}$ century poet and saint ${ }^{5}$ is credited with authorship of the Amra Choluim Chille (hereinafter Amra), an elegy in memory of the saint Columba. Dallán is a diminutive of dall 'blind'. The PN Dallán is attested for another poet, Dallán mac Móire (fl. 900-920, Mac Cana 2004: 19-20).

Considerations of space and the bounds of the topic selected do not allow me to enter into a detailed discussion regarding the date and authorship of the Amra Choluim Chille. ${ }^{6}$ I do not intend to discuss the historicity of the poet himself or the dating of the poem: our main point of interest is his name as it has come down to us in medieval Irish sources.

Information about the poet is contained in the Preface to the Amra, preserved in a number of manuscripts, the earliest being the $11^{\text {th }}$-century $\mathrm{LH}$ (Bisagni 2009: 1-2); this preface was dated by M. Herbert (1989: 72) to the beginning of $11^{\text {th }}$ century.

The name Dallán Forgaill is often regarded as a mysterious nickname:

Dallán Forgaill means 'blind one of superior testimony' (blind poets have not been uncommon in Ireland, as elsewhere); this is most unlikely to have been his original name, but any reliable information about either his name or his family background does not exist (Charles-Edwards 2004).

Dallán is a son of Forgaill in the $9^{\text {th }}$ century Martyrology of Tallaght (where his feast-day is 29 January), which seems to be one of the earliest historical mentions of the poet. Some later sources identify him with one Eóchaid Rígéices, also chief poet of Ireland. Dallán's name and genealogy, as well as his alleged identity with Eóchaid, deserve closer scrutiny.

\footnotetext{
${ }^{5}$ His feast-day is 29 January (MT, MG, MD).

${ }^{6}$ See Herbert 1989 and recently Bisagni 2009.

${ }^{7}$ Regrettably, P. Ó Riain's article on Dallán (2011: 255-6) does not contribute anything to the subject, mainly because of the author's total disregard for the chronology of the sources: the genealogies of the saints, a very late Life of Saint Maedóc and nineteenth-century local traditions (worthwhile as they may be) are taken at face value.
} 


\subsection{The tribal affinities of Dallán Forgaill ${ }^{8}$}

The Preface to the Amra in LU mentioned a tribe called Másraige in connection with Dallán. The Rawl. B 502 and LH redactions also mention the Másraige but they are more detailed: they refer to two famous $10^{\text {th }}-11^{\text {th }}$ century scholars, Ferdomnach, abbot of Kells (d. 1008) ${ }^{9}$ and Máel Suthain úa Cerbaill, "chief sage of Ireland" (ardsuí Érenn, d. 1010), as authorities regarding the circumstances of composition of the Amra.

The earliest version of the Preface to the Amra in the TCD MS 1441 version of the LH presents the following picture: Loc dond Amra usque ad finem .i. in blog talman fil otá Féne in Huib Tigernan im-Midi co Dún na nAirbed i crich (Mas)raidi fri hIrorus anair; no do Cectraigib Slecht a Breifni Connacht i. do Dallán (LH I.162). ${ }^{10}$ Later, the LH Preface gives another geographical description, also mentioning Máel Suthain and Ferdomnach: Hic áth Féni dim im-Midi ro-chanad in molad-so (ut) Máel-suthain dixit. Adfét immorro Fer-domnach comarba, is ar Sligi Assail ro-chanad ótha Dún na nAirbed cosin crois ic Tig Lommán (LH I. 164). ${ }^{11}$ This version of the Preface does not actually describe Dallán's tribal affinity, but rather the place where he made the poem.

The Preface to the $12^{\text {th }}$ century LU version briefly describes Dallán Forgaill as Dallán Forgaill do Masraigib Maige Slecht (LU 295-6), ${ }^{12}$ to which scribe $\mathrm{M}$ adds the gloss .i. i mBrefni Connacht. ${ }^{13}$

The Bodleian Amra (Rawl. B 502) presents at first basically the same information (Dallán mac forgaill do Masraigib Maigi Slecht a Breifne Connacht, Stokes 1899: 36), describing the place of composition in more detail later:

\footnotetext{
${ }^{8}$ An article by M. Ní Dhonnchadha (2010: 567-72) partly deals with this subject. Regrettably, this publication reached us too late to consider it fully. Its arguments to some extent concur with ones that are put forward below. However, M. Ní Dhonnchadha argues that Dallán's Airgialla and Dál Fiatach pedigrees may ultimately be the same, since, as it seems, the Airgialla were artificially attached to the Uí Néill pedigree and probably were original dwellers of an Ulidian (Dál Fiatach) territory. I consider that rather unlikely, since the Airgalla pedigree for Dallán seems to be a very late invention. This question deserves further consideration.

${ }^{9}$ The possible role of Ferdomnach in the development of Columban tradition is touched upon by Herbert 1989: 72-3 and was briefly studied by Meckler 1997: 48-9.

10 'The place for the Amra usque ad finem, i.e. the bit of land that is between Fene in Ui Tigernan in Meath up to Dun na n-Airbed in the district of Masraige eastward of Irarus, or of Chechtraige Slecht from Breifne of Connaught: i.e. for Dallan' (transl. R. Atkinson, LH II: 53).

11 'At Ath Feni in Meath was this eulogy sung, ut Mael-Suthain dixit; but Fer-domnach coarb states that it was at Slige Assail it was sung, from Dun na nAirbed to the Cross at Tig Lommain' (transl. R. Atkinson, LH II: 56, with corrections). Atkinson's translation has "(his) coarb"; in this context the insertion is misleading.

12 'Dallán Forgaill of the Másraige (tribe) from Mag Slecht.'

13 'That is, in Brefne of Connacht.'
} 
Oc Áth Fene immorro im-Mide ro thindscanad in moladsa cosin crois ic Tig Lommain.

Mal suthain dixit:

Ro thinnscanad in t-Amra oc Áth Feine Ollorba, ro forbad co dil in dan. ocon chrois ic Tig Lommain.

Adfet immorro Ferdomnach comarba Coluim cille is ar Sligi[d] Assail ro chanad o tha Dun na nAirbed cosin crois ic Tig Lommain.

(Stokes 1899: 134) ${ }^{14}$

The Másraige are connected with the version supported by Ferdomnach of Kells; Dún na nAirbed or Dún na nAirmed ("Fort of the Fences") was situated in the territory of this tribal group. The place-names in question were studied by P. Walsh (2003: 241). Walsh identifies the territory of Uí Tigernáin as the medieval barony of Moyashel and Magheradernan, and Dún na nAirbed as the townland of Down in barony of Corkaree. On the basis of the reading $i$ crich raide in the Lebor Brec (f. 238 c), ${ }^{15}$ Walsh believed that the actual reading is Crích Raide, the region of Corcu Raíde, who gave their name to medieval Corkaree, and that "in the absence of further evidence for the latter name" (ibid.) the Masraidi in $\mathrm{LH}$ is a scribal mistake. ${ }^{16}$ Another possible identification for the Másraige of our text is a tribe in Mag Slecht named Masraige, ${ }^{17}$ Macraige and Mascraige in different sources; this is probably one and the same obscure subject tribe (aithechthúath, Ó Bríain 1925: 235). A similar name, Mascrige, is recorded among the tribal group known as Déissi Breg in Meath (Pender 1934: 84) ${ }^{18}$ Mascraidi are also attested as a subject tribe in Ulster (CGH 157 31). However, I would suggest that Macraige, Masraidi etc., could also be scribal mistakes for moccu Raídi.

It is not possible to decide whether Dallán actually was believed to be a member of a Westmeath tribal group or whether he merely composed the poem in their territory. Since it was supposed that the poet started to compose the poem after the death of Colum Cille, it is possible to suggest that he did this at home (or, in any case, it was imagined so).

\footnotetext{
14 'At Áth Féne in Meath this Praise was begun, (and continued) as far as the cross at Tech Lommáin.

Mael-suthain dixit.

The Amra was begun at Áth Feine Ollarba:

The poem was lovingly completed at the cross at Tech Lommáin.

Ferdomnach, however, a successor of Columba's, declares that it was recited on Assal's road from Dún na nAirbed to the cross at Tech Lommáin' (transl. in Stokes 1899: 135).

${ }^{15}$ A digital copy of the MS has been made accessible online by the ISOS project.

${ }^{16}$ The LH editors note that the Mas- in Masraidi is illegible in the MS.

${ }^{17}$ The word más 'bottom, fundament' occurs as a name of a geographical feature in Meath: más már-Midi 'bottoms of great Meath' (eDIL 2013, s.v. más).

${ }^{18}$ The reference is to the Book of Lecan, 177, recto.
} 


\subsection{The genealogy of Dallán Forgaill: the Airgialla connection and the question of Dallán's identity with Eóchaid Rígéices}

The Preface to the Amra names three famous poets, Senchán, Dallán and Eóchaid Rígéices (Stokes 1899: 138). Since the retinue of those poets was made of "thrice fifty men" (fifty for each chief poet) it is clear that the author of this text at least regarded Dallán and Eóchaid as two separate persons. Eóchaid is a protagonist in the tale "Why Mongán was deprived of noble issue" (Knott 1916).

The CGSH contains two explicit references identifying Dallán Forgaill with Eóchaid. Both include him in the genealogies of the Airgialla tribal group: $:^{19}$ Eóchaid m. Aililla, .i. Dallan Forgaill, ar slicht Colla Úais (CGSH 633). This genealogy is a part of the recensio minor, a late abbreviation of the saints' genealogies, made in the second half of the $14^{\text {th }}$ century (CGSH xxxix). The poetic genealogies - recensio metrica (CGSH 662.105) - also mention Eóchaid mac Colla (with a nickname Dallan Forguill) as a descendant of one of the Airgialla ancestors, giving the following family tree: Colla Uais Muiredach - Eirc - Colla - Eóchaid (saint). ${ }^{20}$ The dating of the recensio metrica is problematic but it seems that it may have been composed sometime towards the end of the $14^{\text {th }}$ century (CGSH: xl-xli).

The genealogy in 662.105 (recensio metrica) is similar to the Airgialla genealogy in CGH 141 a 44-45, 141 b 10 (Conla Óiss - Ercc - Mac Cairthind - Muiredach), omitting "Colla", the alleged father of Dallán, who seems to be invented ad hoc. The recensio metrica at least makes some sense in terms of chronology (although the compilers of genealogies obviously did not care about the chronological inconsistencies at all). The inclusion of Dallán in this genealogical sequence enabled him to be regarded as a relative of Saint Máedoc of Ferns (Ó Riain 2011: 255, 432). If we try to find the sources for the first genealogy (Eóchaid $\mathrm{m}$. Ailella in the recensio minor), we can again turn to the Airgialla genealogies and find the following sequence (CGH $141 \mathrm{~b} 10$ ff.): Colla Úais - Eircc - Mac Cairthind - Muiredach - Amalgaid - Áed Guaire $^{21}$ - Suibne -Máel Bressail - Ailill - Eóchaid; this Eóchaid is credited with two sons, who continued the line.

\footnotetext{
${ }^{19}$ See Lacey 1999 for the detailed analysis of the Airgialla genealogies.

${ }^{20}$ Eochaid mac Colla os cech druing, dar chomainm Dallan Forguill, mic Eirc mic Muiredaig min mic Colla Uais gan farbrigh. 'Eóchaid, son of Colla - over every crowd Dallán Forgaill by nickname, son of Erc, son of the meek Muiredach, son of Colla Uais without tyranny.'

${ }^{21}$ A grandson of Áed Guaire, Fergus, died in 668 (Lacey 1999: 126).
} 
However, all this Airgialla connection looks rather suspicious. Firstly, the Airgialla genealogies as such do not seem to mention Dallán Forgaill. ${ }^{22}$ Secondly, it looks like it was invented to explain the name Forgaill since the Airgialla genealogies contain the sequence: Conla Óiss - Ercc - Mac Cairthind - Forgco - Eochu (or Eóchaid, CGH 141 a 44-45, 141 b 10 ff). Later, Colgan, adhering to the Airgialla genealogy, made Forgco a woman, Forchella, and Dallán's father here is again Colla, a descendant of Colla Úais (Colgan 1645: 203).

The Preface to the Amra contains what is probably a genuine genealogy of Dallán (at least, uncontaminated by later speculations): Feradach - Ercc [C]alla - Dallan (Stokes 1899: 134). The genealogy of an obscure tribe (this is equally valid for Más(c?)raige and Corcu Roíde) was probably not recorded anywhere, and later scholars did their best to try to connect Dallán with one of the familiar genealogical trees, which contained a Colla and an Erc (even if in reverse order). The Fir Craíbe tribal group in the Airgialla territory was allegedly descended from a son of Colla Úais named Feradach, although the details of this genealogy are not clear (Lacey 1999: 134). ${ }^{23}$ A fascinating possibility is offered by an annalistic entry for the year 812 (AU): Ar Corco Roidhe Midhe la Hua Mac Uais. ${ }^{24}$ It looks like the Uí Mac Úais tribe, having inflicted a heavy defeat on the Corco Roíde (and probably depriving them of independence), had appropriated their famous poet and saint. ${ }^{25}$

The problem of Dallán's origins and his alleged identification with Eóchaid Rígéices becomes even more complicated if we look at the Dál Fiatach genealogies (Senchas Dáil Fiatach, CGH LL 330 b 31 ff.; Meyer 1912: 328 ff.; Ní Dobs 1921: 334 ff.). Here Eóchaid Rígéices is a son of Óengus, son of Dallán and a nephew of Forg. This genealogy makes him a pre-historical or an early historical personality. He is a cousin to Muiredach Muinderg, who supposedly died in 490. The Dál Fiatach tract describes Eóchaid thus: Mac dond Óengus-sin Eocho Rígéices, qui hospitatus apud Daimine 7 qui sepultus est i nDomnuch Cuilind (CGH LL 330 b 40). ${ }^{26}$

\footnotetext{
${ }^{22}$ The "lay" genealogies often mention famous saints, as, for instance, in CGH 141 a 50: Epscop Áed díbad 'Bishop Áed - (died) childless'.

${ }^{23}$ On the same page Lacey states that "The great poet Dallán Forgaill is said, in some sources, to be descendant of this Fearadach also" but does not give the source for this statement. This is probably a conclusion based on the presence of a Feradach in Dallán's genealogy.

24 'A slaughter of the Corco Roíde of Mide by the Uí Mac Úais.'

${ }^{25}$ A king of Corco Roíde, mentioned in 1101, was most probably not a native ruler, but an official appointed by a king of Meath (Byrne 2005: 872).

26 'A son of this Óengus was Eochu the royal sage, who was a guest of Daimíne's and who was buried at Domnach Cuilend.'
} 
One of the versions in the Book of Lecan (Lec. A) ${ }^{27}$ adds to this: .i. Dallán Forgaill is é do-rigni reigne Coluim-cilli. ${ }^{28}$

E. Knott (1916: 155) and M. Dobbs believed that the $5^{\text {th }}$ century nephew of Forgg and the $6^{\text {th }}$ century poet are two separate persons: "This Eocho was cotemporary of Muiridach Muinderg and St. Patrick (430-480). The second Eocho was cotemporary with Fiachna m. Baetain and Colmcille (550-625)" (Ní Dobs 1921: 335). The genealogy mentions that this Eóchaid hospitatus apud Daimine, "was a guest of Daimíne's" (this is omitted in Lec. B), a reference to the legend of the three poets satirising Aéd son of Ainmire, ${ }^{29}$ which also features in the preface to the Amra (Stokes 1899: 138). ${ }^{30}$ Most versions do not include the note regarding Dallán Forgaill. These data are easier to grasp in the form of a following table below:

\begin{tabular}{|l|c|c|c|c|}
\hline \multicolumn{5}{|c|}{ Eocho Rígéices in the Senchas Dáil Fiatach } \\
\hline & $\begin{array}{l}\text { Mac dond } \\
\text { Óengus-sin } \\
\text { Eocho } \\
\text { Rígéices, }\end{array}$ & $\begin{array}{l}\text { qui hospitatus } \\
\text { est apud } \\
\text { Daimíne, }\end{array}$ & $\begin{array}{l}\text { 7 qui sepultus } \\
\text { est i nDomnuch } \\
\text { Cuilind }\end{array}$ & $\begin{array}{l}\text {.i. Dallán } \\
\text { Forgaill is é do- } \\
\text { rigni reigne } \\
\text { Coluim-cilli }\end{array}$ \\
\hline LL (CGH) & + & + & + & - \\
\hline $\begin{array}{l}\text { Lec. A (Ní } \\
\text { Dobs 1921) }\end{array}$ & + & + & + & + \\
\hline $\begin{array}{l}\text { Lec. B (Ní } \\
\text { Dobs 1921) }\end{array}$ & + & - & + & - \\
\hline $\begin{array}{l}\text { Laud 610 } \\
\text { (Meyer 1912) }\end{array}$ & + & + & + & - \\
\hline $\begin{array}{l}\text { BB, f. 94 r } \\
\text { (ISOS) }\end{array}$ & + & + & + & - \\
\hline $\begin{array}{l}\text { D. ii. 1, f. 13 } \\
\text { r= Book of } \\
\text { Uí Maíne } \\
\text { (ISOS) }\end{array}$ & + & + & & \\
\hline
\end{tabular}

\footnotetext{
${ }^{27}$ Dobbs labelled the two versions in the Book of Lecan Lec. A (fol. 249 ff.) and Lec. B (fol. 280 ff.). Her edition is based on $L e c$. B: the reasons for this choice are described in the Introduction to the text (Ní Dobs 1921: 308-9).

28 'That is, Dallán Forgaill, who made a praise to Colum Cille.'

29 'A year they were at Clochar: to Daimín it was no detriment: 'tis there they satirised Áed about the variously-handsome brooch of gold' (transl. Wh. Stokes in Stokes 1899: 139).

${ }^{30}$ I do not believe that the fact that a genealogy is written in Latin is a guarantee of its antiquity (pace Ó Corráin 1998: 193), but nevertheless it can be one of the signs of antiquity, and the Dál Fiatach genealogy in question contains several Latin expressions (quod dicitur ... ut praedictum est... secundum quosdam... qui hospitatus est apud Daimíne et qui sepultus est $i$ nDumnuch Culind... quem benedixit Patricius ut alii dicunt in regnum Hiberniae; see CGH LL 330 b 8 - b $60)$.
} 
To sum up: the identity of Eóchaid and Dallán is stated by 1$)$ two late $\left(14^{\text {th }}\right.$ century) genealogies and 2) a note in one of the versions of Dál Fiatach genealogies in the Book of Lecan (written in the end of $14^{\text {th }}$ century). ${ }^{31}$ It seems that there is reason to believe that Dallán Forgaill and Eóchaid Rígéices were originally two separate persons: the first from Mide and the second from Ulster, probably linked with the Dál Fiatach ruling dynasty. Eóchaid's quarrel with Mongán (Knott 1916), a prince of the Ulster kingdom of Dál nAraide, is further evidence for the poet's Ulster connections. Both did not have a connection of any kind with the Colla Úais and the Airgialla: this connection arose by confusion. Thus, Dallán Forgaill is a PN and not a nickname.

\subsection{The second part of the name: Forgaill}

As a personal name, the word forgell occurs in CGH only once (160 a 21): this was the name of an early historical progenitor of an aicme 'branch' of a Clann Forgill (or Clann Forgaill) of the Uí Ambrit family (Ciarraige). It is possible, of course, that Dallán was a son of a Forgell, as it is stated by The Martyrology of Tallaght.

The Old Irish forgell 'testimony, a statement, authority' is a legal term, which is also found in the name of a noble status, aire forgill. Forgell occurs as a second element in the popular female PN Der(b) Forgaill (O'Brien 1956). Abstract notions and ideas constitute a separate semantic group among the second elements of the "Non-IE" Old Irish PNs: for instance, Máel Anfis (ainfis 'ignorance'), Máel Cothaid (cothad 'support, feeding'), Mac Menman (menmae 'thought'). Some of them are legal or socio-legal terms, for example:

aithe 'restoration, revenge': Máel Aithi (CGH 141 b 26) VN of ad-fen 'repays, requites'; 32

congelt 'act of sharing grazing (with)', also of relationship of a lord and client (céile), VN of con-geil 'the act of grazing together': Cú Chongelt (7 persons in $\mathrm{CGH}$ );

fuigell 'judgment, decision', VN of fo-gella 'submits (a case) to, gives a judgement': Fer Fugaill, d. 789 AU, bishop of Cluáin Dolcáin; ${ }^{33}$ at least two abbots of this monastery belonged to a family of Ua Lugedon, but the bishop, as it seems, did not (Doherty 2000: 184);

\footnotetext{
${ }^{31}$ Colgan was rather skeptical on this point; he was ready to admit that "the proper name (nomen proprium) of the saint was Eóchaid" (1645: 205) on the basis of the Appendix to The Life of Columba by Adomnán, which indeed mentions an Echoid. Colgan also recognized problems with the Airgialla genealogy and especially with the cousinship of Dallán and Máedóc.

${ }^{32}$ The name of this Airgialla prince is spelled as Máel Aichi and as Máel Aithge in Lec. and BB. His brother Fergus, son of Muccaid (or Colmán Muccaid, according to Lec. and BB), died in 668 (AU).

${ }^{33}$ His feast-day is 10 March (MT, MD).
} 
luige 'oath': Dub Luige (d. 761), Máel Luige (CGH 130 a 12);

recht 'right, law': Mac Recht (CGH LL 336 e 58).

I would very tentatively suggest that Dallán Forgaill is a "Non-IE" name with an uncommon first element. Having established the existence of names with the first element cáech 'one-eyed', I do not see any problem in a name with the first element dall 'blind'. The second element of the name is also an argument in favour of this point of view.

The evidence, available to us at the moment, suggests that even if the PN Dallán was originally given as a nickname, it was used as a PN without an alternative "true" name.

\section{Conclusion}

The study of Irish onomastics is still in its infancy. This work is an attempt to sketch one of the future avenues of this study. We realize that this kind of work will always be flawed in many respects until all Irish genealogical material is edited or at least made accessible (on which see Ó Muraile 2010). Nevertheless, this is a promising field. The strong preference for vernacular names in pre-Norman Ireland was consistent with a general tendency in Christian Western societies before the $13^{\text {th }}$ century (as opposed to recently Christianized Eastern Europe, see Filippov 2012). The patterns of name-giving may have reflected subtle tendencies and changes in Irish society, which are not always manifest in the narrative sources created by members of the Irish learned elite. Rare and archaic name-types are especially interesting in this respect.

Lomonosov Moscow State University

\section{Abbreviations}

AU - Mac Airt, S., Mac Niocaill, G., 1983, The Annals of Ulster (to A.D. 1131), Dublin: Dublin Institute for Advanced Studies.

BB - The Book of Ballymote (Royal Irish Academy MS 23 P 12).

CGH - Ó Brien, M.A., ed., 1962, Corpus Genealogiarum Hiberniae, Dublin: Dublin Institute for Advanced Studies.

CGSH - Ó Riain, P., ed., 1985, Corpus Genealogiarum Sanctorum Hiberniae, Dublin: Dublin Institute for Advanced Studies.

Lec. - The Book of Lecan (Royal Irish Academy MS 23 P 2).

LL - The Book of Leinster (Trinity College, Dublin, MS 1339).

LH - Bernard, J.H., Atkinson, R., eds., 1898, The Irish Liber Hymnorum, Edited from the Mss. with Translations, Notes and Glossary. 2 vols., London: Harrison and sons. 
LU - Best, R.I., Bergin O., eds., 1929, Lebor Na hUuidre: Book of the Dun Cow, Dublin: Hodges, Figgis, \& Co. (Royal Irish Academy MS 23 E 25).

MD - Todd, J.H., Reeves W., eds., 1864, The Martyrology of Donegal: A Calendar of the Saints of Ireland, Dublin: Printed for Irish Archaeological and Celtic society by Alexander Thom.

MG - Stokes, Wh., ed., 1895, Félire Húi Gormáin. The Martyrology of Gorman, London: Printed for Henry Bradshaw Society by Harrison and sons. MT - Best, R.I., Lawlor H.J., eds., 1931. The Martyrology of Tallaght from the Book of Leinster and MS. 5100-4 in the Royal Library, Brussels, London: Harrison and Sons.

\section{References}

Bisagni, J., 2009, 'The Language and the Date of Amrae Coluimb Chille', in: Zimmer, S., ed., Kelten am Rhein. Akten des dreizehnten Internationalen Keltologiekongress, Mainz am Rhein, 1-11.

Bhreathnach, M., 1984, 'A New Edition of Tochmarc Becfhola', Ériu 35, 5991.

Byrne, F. J., 2005, 'Ireland and Her Neighbours, c. $1014-c .1072$ ', in: Ó Cróinín, D., ed., A New History of Ireland: I. Prehistoric and Early Ireland, Oxford, 862-98.

Charles-Edwards, T.M., 2006, The Chronicle of Ireland, 2 vols., Liverpool. Clancy, Th. O., 2004, 'Philosopher-King: Nechtan Mac Der-Ilei', The Scottish Historical Review 83 (216), 125-49.

Colgan, J., ed., 1645, Acta Sanctorum Veteris et Maioris Scotiae Seu Hiberniae Sanctorum Insulae, Partim ex Variis per Europam Ms. Codd. Exscripta, Partim ex Antiquis Monumentis \& Probatis Authoribus Eruta \& Congesta; Omnia Notis \& Appendicibus Illustrata, Lovanii: Apud Everardum De Witte.

Dobbs, M.E., 1947, 'The Prefix 'Mess' in Irish Personal Names', Journal of the Royal Society of Antiquaries of Ireland 77(2), 147-9.

Doherty, Ch., 2000, 'Cluain Dolcáin: A Brief Note', in: Smyth, A.P., ed., Seanchas: Studies in Early and Medieval Irish Archaeology, History and Literature in Honour of Francis J. Byrne, Dublin, 182-8.

Doherty, Ch., 2006, 'The Earliest Cult of Macartan', Clogher Record 19(1), 43-69.

Filippov, I., 2012, 'Baptismal Names and Self-Identification in the Early Middle Ages', in: Sabaté F., ed., Identitats, Lleida, 105-44.

Findon, J., 2013, 'Looking for "Mr. Right" in Tochmarc Becfhola', in: Sheehan, S., Dooley, A., eds., Constructing Gender in Medieval Ireland, New York, 57-74. 
Herbert, M., 1989, 'The Preface to Amra Coluim Cille', in: Ó Corráin, D., Breatnach, L., McCone, K., eds., Sages, Saints, and Storytellers: Celtic Studies in Honour of Professor James Carney, Maynooth, 67-75.

Hollo, K., 2005, Fled Bricrenn Ocus Loinges Mac nDuíl Dermait and Its Place in the Irish Literary and Oral Narrative Traditions: A Critical Edition with Introduction, Notes, Translation, Bibliography and Vocabulary, Maynooth.

Joynt, M., 1931, Tromdámh Guaire, Dublin.

Knott, E., 1916, 'Why Mongán was Deprived of Noble Issue', Ériu 8, 155-60. Mac Cana, P., 2004, 'Praise Poetry in Ireland before the Normans', Ériu 54, 11-40.

Meckler, M., 1997, 'The Annals of Ulster and the Date of the Meeting at Druim Cett', Peritia 11, 44-52.

Meyer, K., 1912, 'The Laud Genealogies and Tribal Histories', Zeitschrift für celtische Philologie 8, 291-338.

Ní Dobs, M., 1921, 'The History of the Descendants of Ir', Zeitschrift für celtische Philologie 13, 308-59.

Ní Dhonnchadha, M., 2010, 'The beginnings of Irish vernacular tradition', in: L'Irlanda e gli Irlandesi nell'alto Medioevo: Spoleto, 16-21 aprile 2009, Spoleto, 533-600.

Ó Bríain, M., 1925, 'Studien zu irischen Völkernamen', Zeitschrift für celtische Philologie 15, 222-37.

Ó Brien, M.A., 1956, 'Der- , Dar- , Derb- in Female Names (Etymologies and Notes, No. 15)', Celtica 3, 178-9.

Ó Brien, M.A., 1973, 'Old Irish Personal Names: M.A. O'Brien's 'Rhŷs Lecture'-Notes, 1957' (ed. R. Baumgarten), Celtica 10, 211-36.

Ó Corráin, D., 1998, 'Creating the Past: The Early Irish Genealogical Tradition. Carroll Lecture 1992', Peritia, 12, 177-208.

Ó Cuív, B., 1980-81, 'Topographical Elements in Irish Personal Names', Bulletin of the Ulster Place-name Society (Series Two) 3, 8-12.

Ó Cuív, B., 1986, 'Aspects of Irish Personal Names', Celtica 18, 151-84.

Ó Muraíle, N., 2010, 'The Irish Genealogies - an Overview and Some Desiderata', Celtica 36, 128-45.

Ó Riain, P., 2011. A Dictionary of Irish Saints, Dublin.

O'Donovan, J., ed., 1862, The Topographical Poems of John O'Dubhagain and Gilla na Naomh O'Huidhrin, Dublin.

Pender, S., 1934, 'A Guide to Irish Genealogical Collections', Analecta Hibernica 7, 1-167.

Stokes, W., 1899, 'The Bodleian Amra Choluimb Chille', Revue Celtique 20, 31-55, 132-83, 248-89, 400-37.

Thurneysen, R., 1946, A Grammar of Old Irish, Dublin. 
Uhlich, J., 1993, Die Morphologie der komponierten Personennamen des Altirischen, Bonn.

Walsh, P., 2003, 'Some Place-Names of Ancient Meath', in: Walsh, P., Ó Muraíle., N., eds., Irish Leaders and Learning through the Ages, Dublin, 23861 (repr. from the Irish Ecclesiatical Record, 1932).

\section{Electronic sources}

Charles-Edwards, T. M., 2004, 'Dallán Forgaill (fl. 597)', Oxford dictionary of national biography, Online, Oxford University Press (http://www.oxforddnb.com/index/101007031/Dallan-Forgaill).

eDIL 2013 - Royal Irish Academy's Dictionary of the Irish Language based mainly on Old and Middle Irish materials: Revised electronic edition, Queen's University of Belfast (http://edil.qub.ac.uk/dictionary/search.php).

ISOS - Irish Script on Screen, School of Celtic Studies, Dublin Institute for Advanced Studies (http://www.isos.dias.ie). 